\title{
Clinicopathological significance of cancer stem cells marked by CD133 and KAl1/CD82 expression in laryngeal squamous cell carcinoma
}

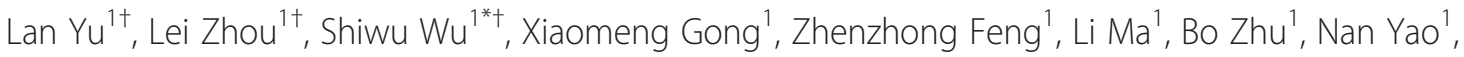 \\ Danna Wang ${ }^{1}$ and Huiming Dong ${ }^{2}$
}

\begin{abstract}
Background: Presently, CD133 is one of the hottest markers to characterize cancer stem cells and KAl1/CD82 is reported as an important marker for the metastasis and prognosis of many cancers. The purpose of our study is to explore the relationship between cancer stem cells (CSCs) marked by CD133 and KAl1/CD82 expression and the clinicopathological characteristics of patients with laryngeal squamous cell carcinoma (LSCC).
\end{abstract}

Methods: Immunohistochemical analysis was used to detect the expression of CD133 and KAl1/CD82 in 83 archival surgical specimens of human LSCC and 83 cases of normal laryngeal tissues.

Results: In LSCC, positive rates of $49.4 \%$ and $41.0 \%$ were obtained for CD133 and KAI1/CD82, respectively. The expression of CD133 in LSCC tissues was significantly higher than that in normal tissues $(P<0.001)$, and the expression of CD133 was positively associated with pTNM stage $(P=0.005)$, pathological grade $(P=0.001)$, and lymph node metastasis $(P<0.001)$. The reduced expression of KAI1/CD82 was present in LSCC tissues. The positive rate of KAl1/CD82 expression was negatively correlated with pTNM stage $(P=0.014)$, pathological grade $(P<0.001)$, and lymph node metastasis $(P=0.007)$. A correlation analysis showed that there was a negative relationship between the expression of CD133 and KAI1/CD82 protein in LSCC tissues $(P<0.001)$. By Kaplan-Meier analysis, the expression of CD133 was negatively correlated with overall survival (OS) (log-rank $=40.949, P<0.001$ ) and diseasefree survival (DFS) (log-rank $=39.307, P<0.001)$ time of LSCC. The expression of KAl1/CD82 was positively correlated with OS (log-rank $=40.279, P<0.001$ ) and DFS (log-rank $=39.271, P<0.001)$ time of LSCC. Cox regression analysis: the expression of CD133 and KAI1/CD82, and PTNM stages were independent prognostic factors of LSCC $(P<0.05)$. Conclusions: Thus the detection of CD133 and KAl1/CD82 proteins may be used as a potential indicator of LSCC prognosis.

\section{Background}

In the United States, laryngeal carcinoma accounted for approximately $0.82 \%$ of new cancer diagnoses and $0.40 \%$ of all cancer deaths in 2012 [1]. The major pathological type of laryngeal cancers is squamous cell carcinoma, accounting for $99 \%$ of laryngeal malignant tumors. Although rapid progress has recently been made in treatment, the prognosis for patients with laryngeal squamous cell

\footnotetext{
* Correspondence: honghongwuwu@sohu.com

${ }^{\dagger}$ Equal contributors

'Department of Pathology, the First Hospital Affiliated to Bengbu Medical College, Bengbu Medical College, 800 Zhihuai Ave, Longzihu, Bengbu, Anhui, China

Full list of author information is available at the end of the article
}

carcinoma (LSCC) remains unsatisfactory. A major problem in finding treatments is the frequent resistance to drugs which emerges. This is linked to the development and maintenance of a small population of tumor cells, termed cancer stem cells (CSCs). These cells have the properties of self-renewal, proliferation, and multilineage differentiation and are responsible for sustaining the tumor [2] and are also thought to initiate tumor metastasis and therapy-resistance [3,4]. A commonly investigated potential CSC marker is CD133 (also known as prominin-1), a $120 \mathrm{kDa}$ five transmembrane domain cell surface glycoprotein, which was initially considered to be one marker of hematopoietic stem cells [5,6]. Now, CD133 may represent a putative cancer stem cell marker

\section{Biomed Central}


in many solid tumors, such as human colon cancer $[7,8]$, breast cancer $[9,10]$, gastric cancer $[11,12]$, glioblastoma [13], lung cancer $[14,15]$, liver cancer $[16,17]$, pancreatic cancer [18], prostate cancer [19], and cholangiocarcinoma [20].

Cancer metastasis involves multiple steps with a high degree of complexity and requires the contribution of a variety of molecules. The KAI1/CD82 gene was originally identified as a suppressor of metastasis of tumor in prostate carcinoma [21]. Recent study has shown that $K A I 1 / C D 82$ gene expression is under-regulated in most metastatic cancers [22]. It is a member of the tetraspan transmembrane superfamily (TM4SF) and is a gene located on human chromosome 11p11.2. KAI1/CD82 plays an important role in cell fusion, adhesion, migration, signaling, fertilization, differentiation, and invasion [22-26]. Decreased KAI1/CD82 expression has been observed to correlate with metastasis and poor prognosis in many human solid tumors, such as prostate cancer [27], lung cancer [28], breast cancer [29], colon cancer [30], gastric cancer [31], liver cancer [32], and kidney cancer [33].

To date, the correlation between CD133 and KAI1/ CD82 expression in LSCC is unknown. Therefore, this study intends to investigate CD133 and KAI1/CD82 expression in the specimens of postoperative LSCC patients following primary laryngeal resection in order to determine the correlation between the expression of CD133 and KAI1/CD82 and clinicopathological characteristics acceptable.

\section{Methods}

\section{Patients and specimens}

Paraffin embedded sections of 83 LSCCs and 83 normal laryngeal tissues were obtained from the Department of Pathology, the First Hospital Affiliated to Bengbu Medical College from January to November 2003. We excluded patients who received preoperative chemotherapy or radiotherapy. Approval for this study was not required by the ethical committee because the experiments carried out did not relate to patient privacy, impairment or treatment. The age of the patients ranged from 43 to 84 years; the median age was 62.1 years. The patients consisted of 75 males and 8 females. There were 43 cases whose tumors were $<2.0 \mathrm{~cm}$ in diameter and 40 cases whose tumors were $\geq 2.0 \mathrm{~cm}$. Thirty were at grade I, 47 were at grade II, and 6 were at grade III, according to the grading system of the World Health Organization. Fifty-one were of supraglottic type, 29 were glottic type, and three were subglottic type. A total of 49 specimens had no lymph node metastasis, whereas 34 specimens showed lymph node metastasis. According to clinical staging of pTNM, 21 were stage I, 32 were stage II, 22 were stage III, and 8 were stage IV.

\section{Immunohistochemical analysis}

All samples were fixed in $10 \%$ buffered formalin and embedded in paraffin. Four- micrometer thick tissue sections were used for analysis. All sections were deparaffinized and dehydrated with graded alcohol. Then, the sections were washed for ten minutes in PBS at $\mathrm{pH}$ 7.2. The endogenous peroxidase activity was quenched by incubation in methanol containing $3 \% \mathrm{H}_{2} \mathrm{O}_{2}$ for ten minutes at room temperature, then heated for 30 minutes at $95^{\circ} \mathrm{C}$ to repair the antigens and finally rinsed in PBS. After several washes in PBS, sections were blocked with goat serum for 20 minutes at room temperature, and then incubated with mouse monoclonal CD133 (Santa Cruz Biotechnology Inc., Santa Cruz, CA, USA) and KAI1/CD82 (Santa Cruz Biotechnology Inc., Santa Cruz, CA, USA) primary antibodies overnight at $4^{\circ} \mathrm{C}$ in a humidified chamber. The slides were treated with polymer enhancer (reagent A) for 20 minutes at room temperature. Washing in PBS, the slides were treated with goat anti-mouse antibody (reagent B) for 30 minutes at room temperature. After a complete wash in PBS, the slides were developed in freshly prepared diaminobenzidine (DAB) solution for eight minutes, and then counterstained with hematoxylin, dehydrated, airdried, and mounted.

Serial sections of LSCC were run in parallel with the primary antibody replaced by PBS and rabbit IgG1 as blank and negative controls.

\section{Evaluation of score}

Slides were reviewed independently by two observers to evaluate the staining pattern of the protein under the light microscope. Ten visual fields were randomly selected from each slide. In scoring expression of CD133 and KAI1/CD82 proteins, both the extent and intensity of immunopositivity were considered. The intensity of the positive result was scored as follows: 0, negative; 1 , weak; 2 , moderate; 3 , strong. The extent of positivity was scored according to the percentage of cells that stained positive: $<10 \%$ is $1 ; 11$ to $50 \%$ is $2 ; 51$ to $75 \%$ is 3 ; $>75 \%$ is 4 . The final score was determined by multiplying the intensity of positivity and the extent of positivity scores, which yielded a range from 0 to 12 . Expression of CD133 and KAI1/CD82 were considered positive when the scores were $\geq 3$.

The positive expression of CD133 was found mainly on the membrane and cytoplasm of LSCC cells and normal laryngeal tissues. The positive expression of KAI1/ CD82 was found mainly on the membrane and cytoplasm of LSCC cells and normal laryngeal tissues. They were presented as a brown granular material.

\section{Statistical analysis}

Fisher's exact test, Pearson Chi-square test for trends in proportions, Spearman's correlate analysis, and Kaplan- 
Meier's method with log-rank test or Cox regression method for univariate or multivariate OS analysis were used to assess the associations among the positive staining of CD133 or KAI1/CD82 and clinicopathological indices. SPSS 17.0 software for windows (Chicago, IL, USA) was used for this purpose. A value of $P<0.05$ was considered statistically significant.

\section{Results}

The association between the expression of CD133 or KAI1/CD82 and clinicopathological factors

CD133 protein was expressed positively in $49.4 \%(41 / 83)$ of LSCC and $4.8 \%(4 / 83)$ of normal laryngeal tissues. There was a significant difference between the LSCC group and the normal laryngeal tissues $(P<0.01)$ (Figure $1 \mathrm{~A}$ and $B)$. There was a positive relationship between the expression of CD133 and histological grade, pTNM stage, and lymph node metastasis $(P<0.05)$. The positive expression of KAI1/CD82 was $41.0 \%(34 / 83)$ in the LSCC group and $96.4 \%(80 / 83)$ in normal laryngeal tissues. A significant difference was found between the LSCC group and the normal group $(P<0.05)$ (Figure $2 \mathrm{~A}$ and $\mathrm{B})$. There was a negative relationship between the expression of KAI1/ CD82 protein and alcohol, histological grade, pTNM stage, and lymph node metastasis $(P<0.05)$. However, the expression of CD133 and KAI1/CD82 was not associated with gender, age, tumor localization, smoking, and tumor diameter $(P>0.05)$ (Table 1$)$.

\section{Prognosis and multivariate analysis}

Follow-up data showed that the OS rate and DFS rate for CD133-positive patients were significantly poorer than that of CD133-negative patients $(P<0.001, P<0.001$, Figure 3$)$. Also, there was a significantly increasing trend in the mean OS survival time and DFS time between the carcinomas with the expression of KAI1/CD82 and those without $(P<0.001, P<0.001$, Figure 4$)$. In the 83 LSCC patients, a univariate analysis (Table 2 ) revealed that the DFS survival significantly correlated with expression of
CD133 $(P<0.001)$ and KAI1/CD82 $(P<0.001)$, tumor location $(P=0.033)$, grade of tumor $(P=0.002)$, lymph node metastasis $(P=0.004)$, and pTNM stages $(P<0.001)$. A multivariate analysis revealed expression of CD133 and KAI1/CD82, lymph node metastasis, and pTNM stages were independent prognostic factors for DFS and OS $(P<0.05)$ (Tables 3 and 4$)$.

\section{Correlation of CD133 and KAI1/CD82 in LSCC}

There was a negative correlation between CD133 expression and KAI1/CD82 expression in LSCC $(\mathrm{r}=-0.578$, $P<0.001)$.

\section{Discussion}

Cancer stem cells (CSCs), also known as tumor initiating cells (TICs), are a subpopulation of tumor cells with the stem cell capacity for self-renewal. They give rise to the differentiated cells, and generate the heterogeneous lineages of cancer cells that comprise the bulk of the tumor $[2,7,11,20,34-39]$. CSCs may originate by malignant transformation of normal stem cells or arise from restricted progenitors of more differentiated cells [40]. The protein CD133 is one of the hot CSC markers in a variety of tumors [7-20]. In this study, we found that the positive expression of CD133 was $49.4 \%$ in LSCC patients. The study investigated the expression of CD133 protein in 83 LSCC specimens with follow-up data and the results indicated that CD133 protein expression level was positively correlative with grade of tumor $(P=0.001)$, lymph node metastasis $(P<0.001)$, and pTNM stage $(P=0.005)$. Furthermore, we also found the expression of CD133 was significantly associated with OS time $(P<0.001)$ and DFS time $(P<0.001)$, suggesting the expression of CD133 might be a potential prognostic factor in LSCC. Another result is that not only LSCC cell express CD133 but also normal laryngeal tissue (squamous epithelial cells). This indicated that CD133 might play an important role in tumorigenesis [8].

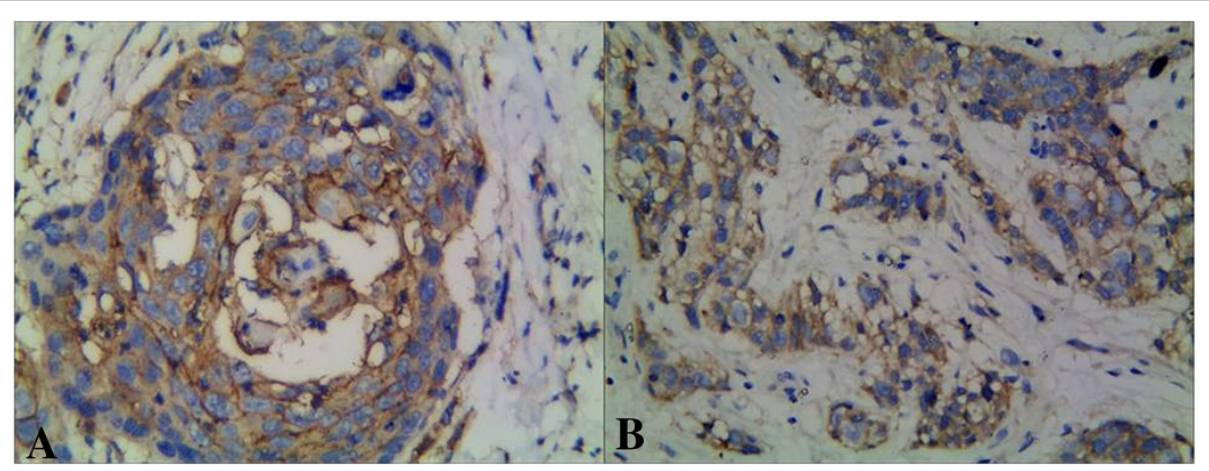

Figure 1 Expression of CD133 protein in laryngeal squamous cell carcinoma. (A) CD133 was expressed as positive in the membrane of cancer cells $(C D 133 \times 400)$. (B) CD133 was expressed as positive in the membrane of cancer cells at the invasive cancer (CD133 $\times 400)$. 


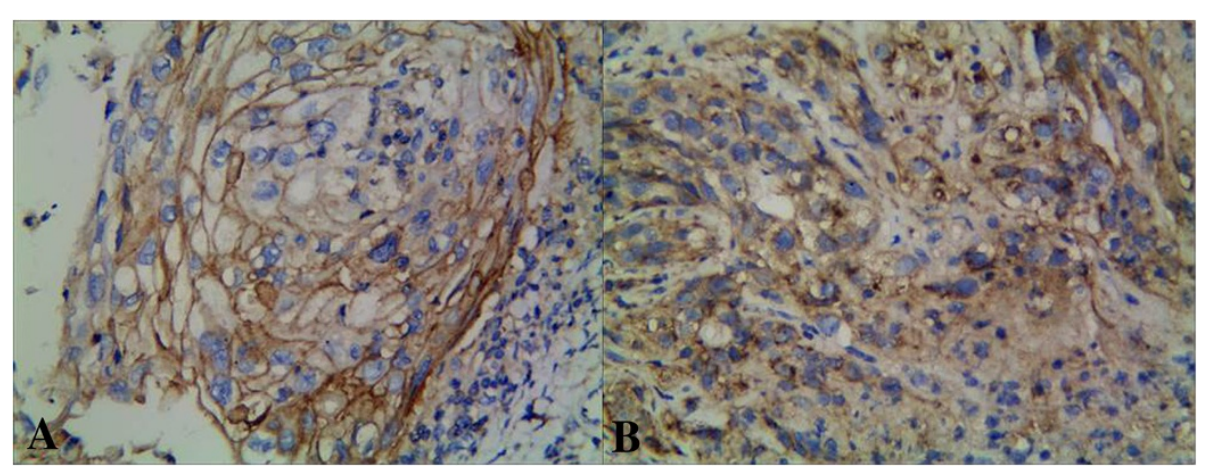

Figure 2 Expression of KAI1/CD82 protein in laryngeal squamous cell carcinoma. (A) KAl1/CD82 was expressed as positive in the membrane of cancer cells (KAl1/CD82 × 400). (B) KAl1/CD82 was expressed as positive in membrane and cytoplasm of cancer cells (KAl1/CD82 ×400).

Table 1 Correlation of CD133 and KAI1/CD82 expression to clinicopathogical characteristics in laryngeal squamous cell carcinoma (LSCC)

\begin{tabular}{|c|c|c|c|c|c|c|}
\hline \multirow[t]{2}{*}{ Variable } & \multicolumn{2}{|c|}{ CD133 } & \multirow[t]{2}{*}{$P$-value } & \multicolumn{2}{|c|}{ KAI1/CD82 } & \multirow[t]{2}{*}{$P$-value } \\
\hline & Negative & Positive & & Negative & Positive & \\
\hline Gender & & & $>0.05$ & & & $>0.05$ \\
\hline Male & 36 & 39 & & 46 & 29 & \\
\hline Female & 6 & 2 & & 3 & 5 & \\
\hline Age & & & $>0.05$ & & & $>0.05$ \\
\hline$<60$ & 15 & 12 & & 15 & 12 & \\
\hline$\geq 60$ & 27 & 29 & & 35 & 22 & \\
\hline Location & & & $>0.05$ & & & $>0.05$ \\
\hline Supraglottic & 26 & 25 & & 26 & 25 & \\
\hline Glottic & 15 & 14 & & 20 & 9 & \\
\hline Subglottic & 1 & 2 & & 3 & 0 & \\
\hline Diameter of tumor & & & $>0.05$ & & & $>0.05$ \\
\hline$<2.0 \mathrm{~cm}$ & 23 & 20 & & 22 & 21 & \\
\hline$\geq 2.0 \mathrm{~cm}$ & 19 & 21 & & 27 & 13 & \\
\hline Smoking & & & $>0.05$ & & & $>0.05$ \\
\hline No & 18 & 13 & & 15 & 16 & \\
\hline Yes & 24 & 28 & & 34 & 18 & \\
\hline Alcohol & & & $>0.05$ & & & $<0.05$ \\
\hline No & 20 & 13 & & 14 & 19 & \\
\hline Yes & 22 & 28 & & 35 & 15 & \\
\hline Grade of tumor & & & $<0.01$ & & & $<0.001$ \\
\hline Well-differentiated & 23 & 7 & & 9 & 21 & \\
\hline Moderately-differentiated & 18 & 29 & & 35 & 12 & \\
\hline Poorly-differentiated & 1 & 5 & & 5 & 1 & \\
\hline Lymph node metastasis & & & $<0.001$ & & & $<0.01$ \\
\hline No & 33 & 16 & & 23 & 26 & \\
\hline Yes & 9 & 25 & & 26 & 8 & \\
\hline pTNM stage & & & $<0.05$ & & & $<0.05$ \\
\hline I and || & 33 & 20 & & 26 & 27 & \\
\hline III and IV & 9 & 21 & & 23 & 7 & \\
\hline
\end{tabular}



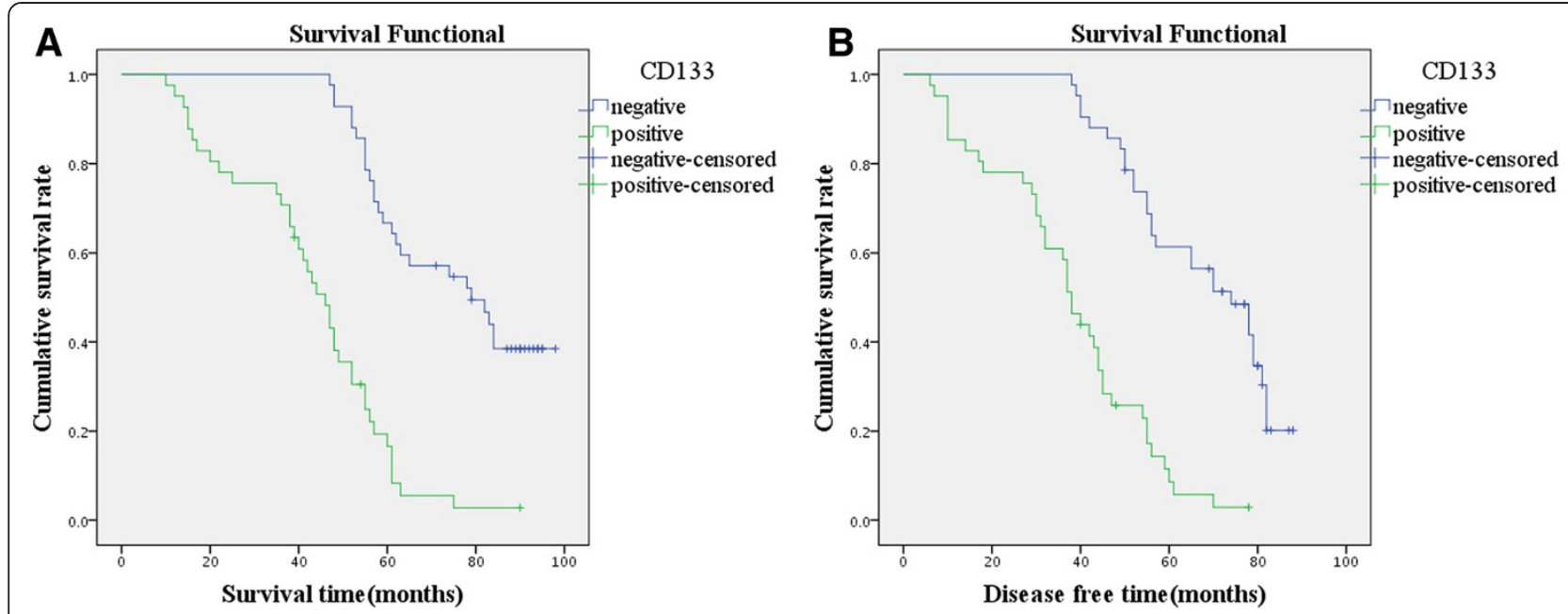

Figure 3 Kaplan-Meier survival analysis by CD133 status $(\mathbf{n}=\mathbf{8 3})$. (A) The green line represents the CD133-positive group patients with a trend of worse survival than the blue line representing CD133-negative group patients (log-rank $=40.949, P=0.000$ ). Mean overall survival (OS) time was 42.4 months for the CD133-positive group and 73.3 months for the CD133-negative group. (B) The green line represents CD133-positive group patients with a trend of worse survival than the blue line representing CD133-negative group patients (log-rank $=39.307, P=0.000)$. Mean DFS for patients was 37.1 months for the CD133-positive group and 65.6 months for the CD133-negative group.

The metastasis suppressor gene $K A I 1 / C D 82$ might be a useful marker for the metastatic and prognostic potential in a series of human tumors. The precise mechanism for the regulation of KAI1/CD82 is unclear. But, in the progression of many tumors, the most common mechanism was downregulation or loss-regulation rather than mutation [22,24]. Our study results showed that $K A I 1 / C D 82$ was negatively associated with grade of tumors $(P<0.001)$, lymph node metastasis $(P=0.007)$, and pTNM stage $(P=0.014)$. From further research, we found that the $K A I / C D 82$-positivegroup correlated with longer survival time, a result which was in agreement with previous reports [32,41,42].

Our research also showed that CD133 expression was negatively correlated with KAI1/CD82 expression $(P<0.001)$. CSCs can manipulate stromal cells to their needs in distant organs and thus prime the foreign soil for their arrival by inducing a premetastatic niche [43]. This indicates that CSCs have high migratory potential and
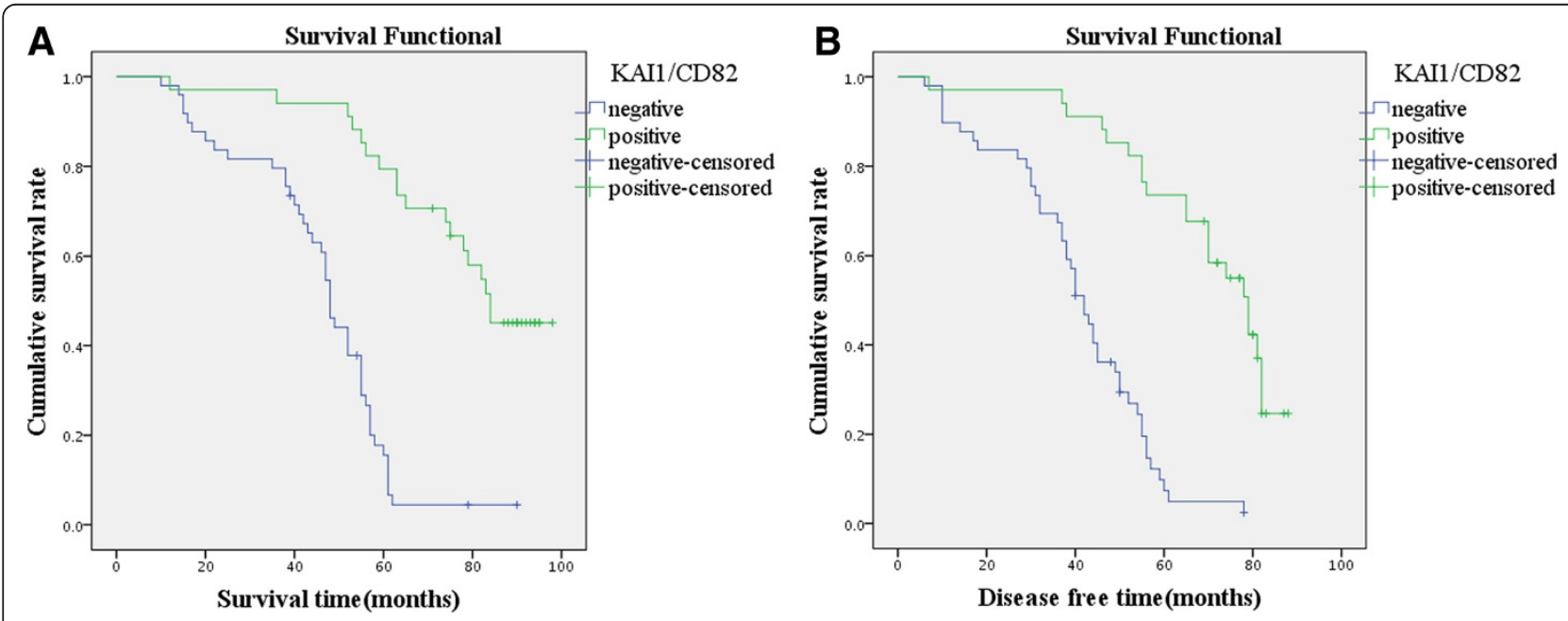

Figure 4 Kaplan-Meier survival analysis by KAI1/CD82 status $(\mathbf{n}=\mathbf{8 3})$. (A) The green line represents the KAl1/CD82-positive patient group with a trend of better survival than the blue line representing the KAl1/CD82-negative patient group (log-rank $=40.279, P=0.000)$. Mean overall survival (OS) time was 76.0 months for the KAl1/CD82-positive group and 45.5 months for the KAl1/CD82-negative group. (B) The green line represents the KAI1/CD82-positive patient group with a trend of better survival than the blue line representing the KAl1/CD82-negative group patients (log-rank $=39.271, P=0.000$ ). Mean DFS patients was 68.0 months for the KAl1/CD82-positive group and 40.1 months for the KAl1/CD82negative group. 
Table 2 Results of univariate analyses of disease-free survival (DFS) and overall survival (OS) time

\begin{tabular}{|c|c|c|c|c|c|}
\hline Variable & $\mathrm{n}$ & $\begin{array}{c}\text { Mean DFS } \\
\text { (months) }\end{array}$ & $P$-value & $\begin{array}{l}\text { Mean OS } \\
\text { (months) }\end{array}$ & $P$-value \\
\hline CD133 & & & $<0.001$ & & $<0.001$ \\
\hline+ & 41 & $42.4 \pm 18.2$ & & $37.1 \pm 17.7$ & \\
\hline- & 42 & $73.3 \pm 16.7$ & & $65.6 \pm 15.4$ & \\
\hline KAl1/CD82 & & & $<0.001$ & & $<0.001$ \\
\hline+ & 34 & $76.0 \pm 19.3$ & & $68.0 \pm 17.5$ & \\
\hline- & 49 & $45.5 \pm 16.8$ & & $40.1 \pm 16.7$ & \\
\hline Gender & & & 0.035 & & 0.067 \\
\hline Male & 75 & $56.4 \pm 23.0$ & & $50.0 \pm 21.9$ & \\
\hline Female & 8 & $73.1 \pm 21.9$ & & $65.6 \pm 17.0$ & \\
\hline Age & & & 0.854 & & 0.280 \\
\hline$<60$ & 27 & $58.2 \pm 21.5$ & & $50.9 \pm 19.5$ & \\
\hline$\geq 60$ & 56 & $57.9 \pm 24.3$ & & $51.8 \pm 23.0$ & \\
\hline Location & & & 0.004 & & 0.065 \\
\hline Supraglottic & 51 & $60.3 \pm 24.1$ & & $53.9 \pm 22.5$ & \\
\hline Glottic & 29 & $56.4 \pm 21.8$ & & $49.6 \pm 20.5$ & \\
\hline Subglottic & 3 & $35.0 \pm 13.7$ & & $29.3 \pm 11.2$ & \\
\hline Diameter of tumor & & & 0.015 & & 0.217 \\
\hline$<2.0 \mathrm{~cm}$ & 43 & $65.5 \pm 19.5$ & & $58.5 \pm 18.5$ & \\
\hline$\geq 2.0 \mathrm{~cm}$ & 40 & $50.0 \pm 24.6$ & & $44.0 \pm 22.9$ & \\
\hline Smoking & & & 0.122 & & 0.132 \\
\hline No & 31 & $62.0 \pm 26.4$ & & $55.3 \pm 22.4$ & \\
\hline Yes & 52 & $55.6 \pm 21.2$ & & $49.3 \pm 20.1$ & \\
\hline Alcohol & & & 0.365 & & 0.163 \\
\hline No & 33 & $62.4 \pm 24.1$ & & $54.9 \pm 22.5$ & \\
\hline Yes & 50 & $55.1 \pm 22.6$ & & $49.2 \pm 21.3$ & \\
\hline Grade of tumor & & & $<0.001$ & & 0.009 \\
\hline Well-differentiated & 30 & $71.7 \pm 18.7$ & & $64.4 \pm 17.6$ & \\
\hline Moderately-differentiated & 47 & $50.4 \pm 22.1$ & & $44.5 \pm 20.7$ & \\
\hline Poorly-differentiated & 6 & $49.3 \pm 25.3$ & & $42.2 \pm 22.8$ & \\
\hline Lymph node metastasis & & & $<0.001$ & & 0.003 \\
\hline No & 49 & $67.6 \pm 18.9$ & & $60.5 \pm 17.4$ & \\
\hline Yes & 34 & $44.2 \pm 22.4$ & & $38.6 \pm 21.3$ & \\
\hline pTNM & & & $<0.001$ & & $<0.001$ \\
\hline I and II & 53 & $68.3 \pm 19.2$ & & $61.3 \pm 17.4$ & \\
\hline III and IV & 30 & $40.0 \pm 18.4$ & & $34.3 \pm 18.0$ & \\
\hline
\end{tabular}

Table 3 Results of multivariate analyses of disease-free survival (DFS) time

\begin{tabular}{cccccc}
\hline Covariate & B & SE & Sig & Exp(B) & 95\%Cl \\
\hline CD133 & 0.747 & 0.354 & 0.035 & 2.110 & 1.055 to 4.221 \\
KAl1/CD82 & -1.282 & 0.432 & 0.003 & 0.278 & 0.119 to 0.647 \\
pTNM & 1.203 & 0.350 & 0.001 & 3.331 & 1.678 to 6.611 \\
Lymph node metastasis & 0.643 & 0.291 & 0.027 & 1.903 & 1.075 to 3.366 \\
\hline
\end{tabular}

Table 4 Results of multivariate analyses of overall survival (OS) time

\begin{tabular}{cccccc}
\hline Covariate & B & SE & Sig & Exp(B) & 95\%Cl \\
\hline CD133 & 0.734 & 0.351 & 0.037 & 2.083 & 1.046 to 4.146 \\
KAl1/CD82 & -1.486 & 0.449 & 0.001 & 0.226 & 0.094 to 0.545 \\
pTNM & 1.191 & 0.349 & 0.001 & 3.292 & 1.659 to 6.530 \\
Lymph node metastasis & 0.747 & 0.287 & 0.009 & 2.110 & 1.203 to 3.701 \\
\hline
\end{tabular}


may be responsible for metastasis [44]. Down-regulation of KAI1/CD82 may further promote the metastatic ability of CSCs. Although the precise molecular mechanism involved in this process is unclear, our research has potential clinical benefits. CD133 and KAI1/CD82 expression, which could be detected by immunohistochemistry, might be a useful molecular marker to predict the prognosis in LSCC patients. It is concluded that the expression of CD133 and KAII/CD82 protein could be correlated with lymph node metastasis, grade of tumor, and pTNM stage in LSCC, and also concluded that they are useful prognostic factors for OS and DFS in LSCC. The combined detection of $\mathrm{CD} 133$ and $K A I 1 / C D 82$ can, to some extent, reflect the biological behavior of LSCC, thus giving the choice of molecular targeting therapy. However, the number of specimens in our study was relatively small. Further studies with larger sized specimens and molecular experiments are needed to verify the present observations.

\section{Conclusions}

It is suggested that CD133 and KAI1/CD82 may play an important role in the evolution of LSCC. And CD133 and $K A I 1 / C D 82$ should be considered as potential marker for the prognosis in patients with LSCC.

\section{Abbreviations \\ LSCC: laryngeal squamous cell carcinoma; CSC: cancer stem cells; pTNM: pathological tumor-node-metastasis; OS: overall survival; DFS: disease free survival; TM4SF: tetraspan transmembrane superfamily; DAB: diaminobenzidine.}

\section{Competing interests}

The authors declare that they have no competing interests.

\section{Authors' contributions}

YL, ZL and WSW carried out the design, analysis of pathology and drafted the manuscript. GXM, FZZ, ML, ZB and YN carried out sample collections and coordination. WDN and DHM performed the immunohistochemical staining. All authors read and approved the manuscript.

\section{Acknowledgments}

We thank all colleagues in Department of Pathology, the First Hospital Affiliated to Bengbu Medical College for their help and support in this study. This study was partially supported by Anhui Province College Excellent Young Talents Found Project (No.2012SQRL094 and 2012SQRL095) and the Natural Science Foundation of Anhui Province (No.1208085MH152) and Education Department of Anhui General Project (KJ2011B100). All authors have contributed greatly, and all authors are in agreement with the content of the manuscript.

\section{Author details}

${ }^{1}$ Department of Pathology, the First Hospital Affiliated to Bengbu Medical College, Bengbu Medical College, 800 Zhihuai Ave, Longzihu, Bengbu, Anhui, China. ${ }^{2}$ Department of Surgical Oncology, the First Hospital Affiliated to Bengbu Medical College Anhui Province, Bengbu Medical College, 800 Zhihuai Ave, Longzihu, Bengbu, Anhui, China.

Received: 28 April 2013 Accepted: 7 April 2014

Published: 24 April 2014

\section{References}

1. Siegel R, Naishadham D, Jemal A: Cancer statistics. CA Cancer J Clin 2012, 62:10-29.
2. Burkert J, Wright NA, Alison MR: Stem cells and cancer: an intimate relationship. J Pathol 2006, 209:287-297.

3. Dalerba P, Cho RW, Clarke MF: Cancer stem cells: models and concepts. Annu Rev Med 2007, 58:267-284.

4. Steeg PS: Tumor metastasis: mechanistic insights and clinical challenges. Nat Med 2006, 12:895-904.

5. Miraglia S, Godfrey W, Yin AH, Atkins K, Warnke R, Holden JT, Bray RA, Waller EK, Buck DW: A novel five-transmembrane hematopoietic stem cell antigen: isolation, characterization, and molecular cloning. Blood 1997, 90:5013-5021.

6. Wu Y, Wu PY: CD133 as a marker for cancer stem cells: progresses and concerns. Stem Cells Dev 2009, 18:1127-1134.

7. Ricci-Vitiani L, Lombardi DG, Pilozzi E, Biffoni M, Todaro M, Peschle C, De Maria R: Identification and expansion of human colon-cancer-initiating cells. Nature 2007, 445:111-115

8. Schneider M, Huber J, Hadaschik B, Sieqers G, Fiebig HH, Schueler J: Characterization of colon cancer cells: a functional approach characterizing CD133 as a potential stem cell marker. BMC Cancer 2012, 12:96.

9. Zhao P, Lu Y, Jiang X, Li X: Clinicopathological significance and prognostic value of CD133 expression in triple-negative breast carcinoma. Cancer Sci 2011, 102:1107-1111.

10. Di Bonito M, Collina F, Cantile M, Camerlingo R, Cerrone M, Marra L, Liguori G, Pirozzi G, Botti G: Aberrant expression of cancer stem cells marker prominin-1 in low-grade tubulobular breast carcinoma: a correlative study between qRT-PCR, flow-cytometric and immunohistochemistry analysis. J Breast Cancer 2012, 15:15-23.

11. Wang T, Ong CW, Shi J, Srivastava S, Yan B, Cheng CL, Yong WP, Chan SL, Yeoh KG, lacopetta B, Salto-Tellez M: Sequential expression of putative stem cell markers in gastric carcinogenesis. $\mathrm{Br} J$ Cancer 2011, 105:658-665.

12. Yang ZL, Zheng Q, Yan J, Pan Y, Wang ZG: Upregulated CD133 expression in tumorigenesis of colon cancer cells. World J Gastroenterol 2011, 17:932-937.

13. Brescia P, Richichi C, Pelicci G: Current strategies for identification of glioma stem cells: adequate or unsatisfactory? J Oncol 2012, 2012:376894.

14. Hsu HS, Huang PI, Chang YL, Tzao C, Chen YW, Shih HC, Hung SC, Chen YC, Tseng LM, Chiou SH: Cucurbitacin I inhibits tumorigenic ability and enhances radiochemosensitivity in nonsmall cell lung cancer-derived CD133-positive cells. Cancer 2011, 117:2970-2985.

15. Janikova M, Skarda J, Dziechciarkova M, Radova L, Chmelova J, Krejci V, Sedlakova E, Zapletalova J, Langova K, Klein J, Grygarkova I, Kolek V: Identification of CD133+/Nestin + putative cancer stem cells in nonsmall cell lung cancer. Biomed Pap Med Fac Univ Palacky Olomouc Czech Repub 2010, 154:321-326.

16. Yu XH, Xu LB, Zeng H, Zhang R, Wang J, Liu C: Clinicopathological analysis of 14 patients with combined hepatocellular carcinoma and cholangiocarcinoma. Hepatobiliary Pancreat Dis Int 2011, 10:620-625.

17. Kordes C, Sawitza I, Müller-Marbach A, Ale-Agha N, Keitel V, KlonowskiStumpe H, Häussinger D: CD133+ hepatic stellate cells are progenitor cells. Biochem Biophys Res Commun 2007, 352:410-417.

18. Kim MP, Fleming JB, Wang H, Abbruzzese JL, Choi W, Kopetz S, McConkey DJ, Evans DB, Gallick GE: ALDH activity selectively defines an enhanced tumor-initiating cell population relative to CD133 expression in human pancreatic adenocarcinoma. PLoS One 2011, 6:e20636

19. Trerotola M, Rathore S, Goel HL, Li J, Alberti S, Piantelli M, Adams D, Jiang Z, Languino LR: CD133, Trop-2 and alpha2beta1 integrin surface receptors as markers of putative human prostate cancer stem cells. Am J Transl Res 2010, 2:135-144.

20. Fan $L$, He F, Liu H, Zhu J, Liu Y, Yin Z, Wang L, Guo Y, Wang Z, Yan Q, Huang G: CD133: a potential indicator for differentiation and prognosis of human cholangiocarcinoma. BMC Cancer 2011, 11:320.

21. Dong JT, Lamb PW, Rinker-Schaeffer CW, Vukanovic J, Ichikawa T, Isaacs JT, Barrett JC: KAl1, a metastasis suppressor gene for prostate cancer on human chromosome 11p11.2. Science 1995, 268:884-886.

22. Malik FA, Sanders AJ, Jiang WG: KAI-1/CD82, the molecule and clinical implication in cancer and cancer metastasis. Histol Histopathol 2009, 24:519-530

23. Lazo PA: Functional implications of tetraspanin proteins in cancer biology. Cancer Sci 2007, 98:1666-1677. 
24. Miranti CK: Controlling cell surface dynamics and signaling: how CD82/ KAl1 suppresses metastasis. Cell Signal 2009, 21:196-211.

25. Malik FA, Sanders AJ, Kayani MA, Jiang WG: Effect of expressional alteration of KAl1 on breast cancer cell growth, adhesion, migration and invasion. Cancer Genomics Proteomics 2009, 64:205-213.

26. Yáñez-Mó M, Barreiro O, Gordon-Alonso M, Sala-Valdés M, Sánchez-Madrid F: Tetraspanin-enriched microdomains: a functional unit in cell plasma membranes. Trends Cell Biol 2009, 19:434-446.

27. Liu W, liizumi-Gairani M, Okuda H, Kobayashi A, Watabe M, Pai SK, Pandey PR, Xing F, Fukuda K, Modur V, Hirota S, Suzuki K, Chiba T, Endo M, Sugai T, Watabe K: KAl1 gene is engaged in NDRG1 gene-mediated metastasis suppression through the ATF3-NFkappaB complex in human prostate cancer. J Biol Chem 2011, 286:18948-18959.

28. Goncharuk VN, del-Rosario A, Kren L, Anwar S, Sheehan CE, Carlson JA, Ross JS: Co-downregulation of PTEN, KAl-1, and nm23-H1 tumor/metastasis suppressor proteins in non-small cell lung cancer. Ann Diagn Pathol 2004, 8:6-16.

29. Mooez S, Malik FA, Kayani MA, Rashid R, Zahid A, Khan A: Expressional alterations and transcript isoforms of metastasis suppressor genes (KAl1 and KiSS1) in breast cancer patients. Asian Pac J Cancer Prev 2011, 12:2785-2791.

30. Wu DH, Liu L, Chen LH, Ding YQ: KAl1 gene expression in colonic carcinoma and its clinical significances. World J Gastroenterol 2004, 10:2245-2249.

31. Chen Z, Gu S, Trojanowicz B, Liu N, Zhu G, Dralle H, Hoang-Vu C: Down-regulation of TM4SF is associated with the metastatic potential of gastric carcinoma TM4SF members in gastric carcinoma. World J Surg Oncol 2011, 9:43.

32. Guo C, Liu QG, Zhang L, Song T, Yang X: Expression and clinical significance of $\mathrm{p53}$, JunB and KAl1/CD82 in human hepatocellular carcinoma. Hepatobiliary Pancreat Dis Int 2009, 8:389-396.

33. Kauffman EC, Barocas DA, Chen YT, Yang XJ, Scherr DS, Tu JJ: Differential expression of KAl1 metastasis suppressor protein in renal cell tumor histological subtypes. J Urol 2009, 181:2305-2311.

34. Reya T, Morrison SJ, Clarke MF, Weissman IL: Stem cells, cancer, and cancer stem cells. Nature 2001, 414:105-111.

35. Singh SK, Hawkins C, Clarke ID, Squire JA, Bayani J, Hide T, Henkelman RM, Cusimano MD, Dirks PB: Identification of human brain tumour initiating cells. Nature 2004, 432:396-401.

36. O'Brien CA, Pollett A, Gallinger S, Dick JE: A human colon cancer cell capable of initiating tumour growth in immunodeficient mice. Nature 2007, 445:106-110.

37. Rosen $\mathrm{JM}$, Jordan $\mathrm{CT}$ : The increasing complexity of the cancer stem cell paradigm. Science 2009, 324:1670-1673.

38. Martins-Neves SR, Lopes AO, do Carmo A, Paiva AA, Simões PC, Abrunhosa AJ, Gomes CM: Therapeutic implications of an enriched cancer stem-like cell population in a human osteosarcoma cell line. BMC Cancer 2012, 12:139.

39. Chen L, Kasai T, Li Y, Sugii Y, Jin G, Okada M, Vaidyanath A, Mizutani A, Satoh A, Kudoh T, Hendrix MJ, Salomon DS, Fu L, Seno M: A model of cancer stem cells derived from mouse induced pluripotent stem cells. PLoS One 2012, 7:e33544.

40. Visvader JE, Lindeman GJ: Cancer stem cells in solid tumours: accumulating evidence and unresolved questions. Nat Rev Cancer 2008, 8:755-768.

41. Muneyuki T, Watanabe M, Yamanaka M, Shiraishi T, Isaji S: KAl1/CD82 expression as a prognostic factor in sporadic colorectal cancer. Anticancer Res 2001, 21:3581-3587.

42. Shiwu W, Lan Y, Wenging S, Lei Z, Yisheng T: Expression and clinical significance of CD82/KAl1 and E-cadherin in non-small cell lung cancer. Arch Iran Med 2012, 15:707-712.

43. Fessler E, Dijkgraaf FE, Melo FD, Medema JP: Cancer stem cell dynamics in tumor progression and metastasis: is the microenvironment to blame? Cancer Lett 2013, 341:97-104.

44. Salnikov AV, Liu L, Platen M, Gladkich J, Salnikova O, Ryschich E, Mattern J, Moldenhauer G, Werner J, Schemmer P, Büchler MW. Herr I: Hypoxia induces EMT in low and highly aggressive pancreatic tumor cells but only cells with cancer stem cell characteristics acquire pronounced migratory potential. PLoS One 2012, 7:e46391.

doi:10.1186/1477-7819-12-118

Cite this article as: Yu et al: Clinicopathological significance of cancer stem cells marked by CD133 and KAl1/CD82 expression in laryngeal squamous cell carcinoma. World Journal of Surgical Oncology 2014 12:118.

\section{Submit your next manuscript to BioMed Central and take full advantage of:}

- Convenient online submission

- Thorough peer review

- No space constraints or color figure charges

- Immediate publication on acceptance

- Inclusion in PubMed, CAS, Scopus and Google Scholar

- Research which is freely available for redistribution 